Journal of Epidemiology and Public Health (2019), 4(4): 338-350

https://doi.org/10.26911/jepublichealth.2019.04.04.09

\title{
Factors Affecting Occurrence of Depression in Patients with Cervical Cancer at Dr. Moewardi Hospital Surakarta, Central Java: A Path Analysis Model
}

\author{
Dewi Shinta'), Didik Gunawan Tamtomo²), RB Soemanto3) \\ ${ }^{1)}$ Masters Program in Public Health, Universitas Sebelas Maret \\ 2)Faculty of Medicine, Universitas Sebelas Maret \\ 3)Faculty of Social and Political Sciences, Universitas Sebelas Maret
}

\begin{abstract}
Background: Cervical cancer is in the second place among the incidence of new cases and in thethird highest death from cancer. Cancer depression and severity generally occur together with psychological problems, such as anxiety, pain and fatigue. Most studies in cancer patients have focused on morbidity or mortality more due to the risk of depression. The purpose of this study was to analyze the factors that influence depression in cervical cancer patients.

Subjects and Method: A cross sectional study was conducted at Dr. Moewardi Hospital, Surakarta, Central Java, from September to October 2019. A sample of 200 cervical cancer patients was selected by simple random sampling. The dependent variable was depression. The independent variables were marital status, education, occupation, family income, peer support, family support, health personnel support, coping strategy, cancer stage, frequency of chemotherapy, and length of illness from diagnosis. Depression was measured by the Beck Depression Inventory-II (BDI-II) questionnaire. The other data were collected by medical record and questionnaire. The data were analyzed by path analysis run on Stata 13.

Results: Severe depression in cervical cancer patients was directly increased by the frequency of chemotherapy 3 times $(b=1.80 ; 95 \% C I=0.11$ to $3.49 ; p=0.037)$, advanced stage $(b=2.50 ; 95 \%$ $\mathrm{CI}=0.18$ to $4.82 ; \mathrm{p}=0.035)$, and length of illness from diagnosis $\geq 11$ months $(\mathrm{b}=2.27 ; 95 \% \mathrm{CI}=$ 0.57 to $3.96 ; \mathrm{p}=0.009)$. Severe depression was directly decreased by high coping strategy $(\mathrm{b}=-$ 6.33; $95 \% \mathrm{CI}=-8.68$ to $-3.98 ; \mathrm{p}<0.001)$. Severe depression was indirectly affected by peer support, family support, support of health personnel, family income, occupation, education, and marital status.

Conclusion: Severe depression in cervical cancer patients is directly increased by the frequency of chemotherapy 3 times, advanced stage, and length of illness from diagnosis $\geq 11$ months. Severe depression is directly decreased by high coping strategy. Severe depression is indirectly affected by peer support, family support, support of health personnel, family income, occupation, education, and marital status.
\end{abstract}

Keywords: depression, cervical cancer, path analysis

\section{Correspondence:}

Dewi Shinta. Masters Program in Public Health, Universitas Sebelas Maret. Jl. Ir. Sutami 36A, Surakarta, Central Java, Indonesia. Email: shintadw94@gmail.com. Mobile: 082364950175

BACKGROUND
Every year, more than 300,000 women die
from cervical cancer. More than half a mill-
ion women are diagnosed (WHO, 2019).
Cervical cancer is the second highest inci-
dence of new cases and the third highest
cancer death. The number of events in

Indonesia was 32,469 (10.69\%) new cases of cervical cancer and 18,279 (10.27\%) cases of cervical cancer deaths in Indonesia (Global Burden Cancer, 2019).

Depression and cancer generally occur together with psychological problems, such as anxiety, pain and fatigue. 
Most studies in cancer patients have focused on morbidity or mortality due to the risk of depression rather than depression as a risk factor for subsequent cancer. Since the 1980s, studies have reported that depression is involved in immune function, endocrine function, cancer metastasis, tolerance of treatment, and other processes (Jia et al., 2017). Previous research in 2017 showed that patients with major depression were 14.83 times more likely to have a poor quality of life compared to moderate or mild depression (Adriani et al., 2017).

Depression not only significantly reduces the quality of life, but can also increase cancer recurrence rates and risk of death (Wen et al., 2018). In addition to physical discomfort, cancer patients generally have to manage financial burdens and emotional distress. Depressed patients may have noncompliance with treatment recommendations, in addition to the impact of general functioning and quality of life. In addition, patients who receive cancer chemotherapy treatment, may experience delayed symptoms, including sleep disorders, depressed moods, and fatigue. This is more likely to develop depression (Shyu et al., 2019). There is a need to prevent depression and anxiety in long-term cancer patients, individual treatment of physical and psychological symptoms which is as important as social support and professional counseling (Götze et al., 2019).

\section{SUBJECTS AND METHOD \\ 1. Study Design \\ This was an analytic observational study with a cross sectional design. The study was carried out at Dr. Moewardi Hospital, Surakarta, Central Java, from September to October 2019.}

\section{Population and Sample}

The population in this study consisted of cervical cancer patients at Dr Moewardi
Hospital, Surakarta. A sample of 200 cancer patients was selected randomly.

\section{Study Variables}

The dependent variable was depression. The independent variables were marital status, education, occupation, family income, peers support, family support, health personnel support, coping strategy, cancer stage, frequency of chemotherapy, and length of illness from diagnosis.

4. Operational Definition of Variables Depression was a tense and life changing event that can evoke feelings of fear, worry, sadness, and anger in cervical patients as research subjects. The measuring instrument used was the Beck Depression Invetory-II (BDI-II) questionnaire. The measurement scale was continous, but it was transformed into dichotomous, coded o for mild and 1 for severe.

Education was a formal level of education ever pursued by the subjects based on the last diploma obtained. The data were collected by questionnaire. The measurement scale categorical, coded o for $<$ Senior high school and 1 for $\geq$ Senior high school.

Marital status was a marriage bond that has been ratified by the KUA (Office of Religious Affairs). The data were collected by questionnaire. The measurement scale categorical, coded o for unmarried and 1 for married.

Occupation was an activity carried out every day by the subjects. The data were collected by questionnaire. The measurement scale categorical, coded o for unemployed and 1 for employed.

Family income was the total income obtained by family members by working with average monthly income in the past 6 months. The data were collected by questionnaire. The measurement scale was continous, but it was transformed into dichoto-

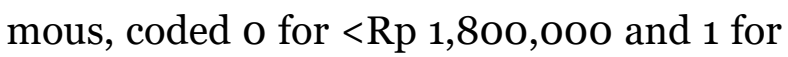
$\geq \operatorname{Rp} 1,800,000$. 
Peers support was support from friends, in the form of helping or paying attention to the subjects during cervical cancer diagnosis. The data were collected by questionnaire. The measurement scale was continous, but it was transformed into dichotomous, coded o for weak and 1 for strong.

Family support was support from family members in the form of helping or giving attention to the subjects during cervical cancer diagnosed. The data were collected by questionnaire. The measurement scale was continous, but it was transformed into dichotomous, coded o for weak and 1 for strong.

The support of health personnel was the support of health personnel who work in hospitals, including nurses, midwives and doctors who help, pay attention, and provide information to the subjects during the treatment. The data were collected by questionnaire. The measurement scale was continous, but it was transformed into dichotomous, coded $\mathrm{o}$ for low and 1 fro high.

Coping strategy was a way that individuals do to solve problems, adjust to changes in response to situations facing depression. The data were collected by questionnaire. The measurement scale was continous, but it was transformed into dichotomous, coded $\mathrm{o}$ for low and 1 for high.

Cancer stage is the level of cervical cancer malignancy according to FIGO 2000, and has been confirmed based on anatomic pathology examination. The data were obtained from medical record of pathology and anatomy examination. The measurement scale categorical, coded o for initial stage and 1 for advanced stage.

Length of illness from diagnosis was the duration of time since staging is determined by a specialist oncologist-gynecolo- gist until the time of the study conducted. The data were obtained from medical record of pathology and anatomy examination. The measurement scale was continous, but it was transformed into dichotomous, coded o for $<11$ months and 1 for $\geq 11$ months.

The frequency of chemotherapy was a cancer treatment using sitostatica drugs that are substances that inhibit the proliferation of cancer cells. The data were obtained from medical record. The measurement scale was continous, but it was transformed into dichotomous, coded o for $<3$ times and 1 for $\geq 3$ times.

\section{Research Ethics}

This research was conducted based on research ethics, namely informed consent, anonymity, confidentiality, and ethical research. Research ethics was obtained from the Research Ethics Committee in Dr. Moewardi Hospital, Surakarta, Indonesia, No. 1,050 / VIII / HREC / 2019.

$\frac{\text { RESULTS }}{\text { 1. Sample Characteristics }}$

Table 1 showed sample characteristics (continous data). The categorical data sample was described in the Table 2.

Table 2 shows that 126 patients experienced mild depression (63\%) and 74 patients experienced severe depression (37\%). Cervical cancer patients are mostly married (79.5\%), had low education ( $<$ Senior high school) (66.5\%), unemployed (6o\%), family income $<$ Rp 1,800,000 (67.5\%), strong peer support (65.5\%), strong family support (62\%), strong health personnel support (66\%), and high coping strategy (66\%). 144 patients (72\%) were in the advanced stage, $54.5 \%$ patients were diagnosed at $<11$ months, and had chemotherapy frequency $<3$ times 105 patients (52.5\%). 
Shinta et al./ Factors affecting occurrence of depression in cervical cancer patients

Table1. Sample characteristics of continuous data

\begin{tabular}{lccccc}
\hline \multicolumn{1}{c}{ Variables } & n & Mean & SD & Min. & Max. \\
\hline Depression & 200 & 26.12 & 8.61 & 10 & 49 \\
Peers support & 200 & 10.96 & 1.61 & 8 & 14 \\
Family support & 200 & 12.05 & 1.67 & 9 & 14 \\
Health personnel support & 200 & 11.01 & 0.98 & 9 & 12 \\
Coping strategy & 200 & 17.11 & 1.83 & 13 & 20 \\
Length of illness from diagnosis & 200 & 11.24 & 10.17 & 0 & 50 \\
Chemotherapy frequency & 200 & 3 & 3.32 & 0 & 15 \\
Family income (rupiah) & 200 & $1,366,750$ & 76.69 & 400,000 & $3,800,000$ \\
\hline
\end{tabular}

2. Univariate Analysis

Table 2. The description of the characteristics of the categorical data sample

\begin{tabular}{llcc}
\hline \multicolumn{1}{c}{ Variable } & \multicolumn{1}{c}{ Category } & n & \% \\
\hline Depression & Mild & 126 & 63.00 \\
Marital Status & Severe & 74 & 37.00 \\
& Unmarried & 41 & 20.50 \\
Education & Married & 159 & 79.50 \\
& < Senior high school & 133 & 66.50 \\
Occupation & $\geq$ Senior high school & 67 & 33.50 \\
& Unemployed & 120 & 60.00 \\
Family Income & Employed & 80 & 40.00 \\
Peers Support & $<$ Rp 1,80o,ooo & 135 & 67.50 \\
& $\geq$ Rp 1,80o,ooo & 65 & 32.50 \\
Family Support & Weak (score <11) & 69 & 34.50 \\
& Strong (score $\geq 11)$ & 131 & 65.50 \\
Health Personnel Support & Weak (score <12) & 76 & 38.00 \\
& Strong (score $\geq 12)$ & 124 & 62.00 \\
Coping Strategy & Weak (score $<11)$ & 68 & 34.00 \\
& Strong (score $\geq 11)$ & 132 & 66.00 \\
Cancer Stadium & Low (score $<17)$ & 68 & 34.00 \\
& High (score $\geq 17)$ & 132 & 66.00 \\
Length of illness from diagnosis & Beginning & 56 & 28.00 \\
& Advanced & 144 & 72.00 \\
Chemotherapy & $<11$ months & 109 & 54.50 \\
& $\geq 11$ months & 91 & 45.50 \\
& $<3$ times & 105 & 52.50 \\
& $\geq 3$ times & 95 & 47.50 \\
\hline
\end{tabular}

Table 3 shows that the results of bivariate analysis on the factors affecting depression in cervical cancer patients. Table 3 showed that married $(\mathrm{OR}=0.04 ; \mathrm{p}$ $<$ o.001), education $\geq$ Senior high school $(\mathrm{OR}=0.06 ; \mathrm{p}<0.001)$, employed $(\mathrm{OR}=$ 0.13; $\mathrm{p}<0.001)$, family income $\geq \mathrm{Rp}$ $1,800,000 \quad(\mathrm{OR}=0.15 ; \mathrm{p}<0.001)$, strong peer support $(\mathrm{OR}=0.01 ; \mathrm{p}<0.001)$, strong family support $(\mathrm{OR}=0.02 ; \mathrm{p}<0.001)$, strong health personnel support $(\mathrm{OR}=0.01$; $\mathrm{p}<0.001)$, high coping strategy $(\mathrm{OR}=$ 0.003; $\mathrm{p}<0.001)$ decreased depression in cervical cancer patients. Advanced stage of cervical canver $(\mathrm{OR}=7.46 ; \mathrm{p}<0.001)$, length of illness from diagnosis $\geq 11$ months $(\mathrm{OR}=17.28 ; \mathrm{p}<0.001)$, and frequency of chemotherapy $\geq 3$ times $(\mathrm{OR}=14.56 ; \mathrm{p}$ $<0.001$ ) increased depression in cervical cancer patients. 
Journal of Epidemiology and Public Health (2019), 4(4): 338-350

https://doi.org/10.26911/jepublichealth.2019.04.04.09

3. Bivariate Analysis

Table 3. Chi-square test of factors affecting depression of cervical cancer patients

\begin{tabular}{|c|c|c|c|c|c|c|}
\hline \multirow{3}{*}{ Independent Variable } & \multicolumn{4}{|c|}{ Depression } & \multirow{3}{*}{ OR } & \multirow{3}{*}{$\mathbf{p}$} \\
\hline & \multicolumn{2}{|c|}{ Mild } & \multicolumn{2}{|c|}{ Severe } & & \\
\hline & $\mathbf{n}$ & $\%$ & $\mathbf{n}$ & $\%$ & & \\
\hline \multicolumn{7}{|l|}{ Marital Status } \\
\hline Widow & 5 & 12.20 & 36 & 87.80 & \multirow[t]{2}{*}{0.04} & \multirow[t]{2}{*}{$<0.001$} \\
\hline Married & 121 & 76.10 & 38 & 23.90 & & \\
\hline \multicolumn{7}{|l|}{ Education } \\
\hline Low $(<$ SHS $)$ & 63 & $47 \cdot 37$ & 70 & 52.63 & \multirow[t]{2}{*}{0.06} & \multirow[t]{2}{*}{$<0.001$} \\
\hline $\operatorname{High}(\geq$ SHS $)$ & 63 & 94.03 & 4 & 5.97 & & \\
\hline \multicolumn{7}{|l|}{ Occupation } \\
\hline Not working/jobless & 56 & 46.67 & 64 & 53.33 & \multirow[t]{2}{*}{0.13} & \multirow{2}{*}{$<0.001$} \\
\hline Working & 70 & 87.50 & 10 & 12.50 & & \\
\hline \multicolumn{7}{|l|}{ Family Income } \\
\hline$<$ Rp. $1,800,000$ & 69 & 51.11 & 66 & 87.69 & \multirow[t]{2}{*}{0.15} & \multirow[t]{2}{*}{$<0.001$} \\
\hline$\geq$ Rp. $1,800,000$ & 57 & 87.69 & 8 & 12.31 & & \\
\hline \multicolumn{7}{|l|}{ Peers Support } \\
\hline Weak $(<11)$ & 7 & 10.14 & 62 & 89.86 & \multirow[t]{2}{*}{0.01} & \multirow[t]{2}{*}{$<0.001$} \\
\hline Strong ( $\geq 11)$ & 119 & 90.84 & 12 & 9.16 & & \\
\hline \multicolumn{7}{|l|}{ Family Support } \\
\hline Weak $(<12)$ & 13 & 17.11 & 63 & 82.89 & \multirow[t]{2}{*}{0.02} & \multirow[t]{2}{*}{$<0.001$} \\
\hline Strong $(\geq 12)$ & 113 & 91.13 & 11 & 8.87 & & \\
\hline \multicolumn{7}{|l|}{ Health Personnel Support } \\
\hline Weak $(<11)$ & 5 & $7 \cdot 35$ & 63 & 92.65 & \multirow[t]{3}{*}{0.01} & \multirow[t]{2}{*}{$<0.001$} \\
\hline Strong $(\geq 11)$ & 121 & 91.67 & 11 & 8.33 & & \\
\hline \multicolumn{6}{|l|}{ Coping Strategy } & \\
\hline Low $(<17)$ & 3 & 4.41 & 65 & 95.59 & 0.01 & $<0.001$ \\
\hline High $(\geq 17)$ & 123 & 93.18 & 9 & 6.82 & & \\
\hline Cancer Stage & & & & & & \\
\hline Beginning & 50 & 89.29 & 6 & 10.71 & 7.46 & $<0.001$ \\
\hline Advanced & 76 & 52.78 & 68 & 47.22 & & \\
\hline Length of illness from diag & & & & & & \\
\hline$<11$ months & 97 & 88.99 & 12 & 11.01 & 17.28 & $<0.001$ \\
\hline$\geq 11$ months & 29 & 31.87 & 62 & 68.13 & & \\
\hline Frequencyof Chemoterapy & & & & & & \\
\hline$<3$ times & 93 & 88.57 & 12 & 11.43 & 14.56 & $<0.001$ \\
\hline$\geq 3$ times & 33 & 34.74 & 62 & 65.26 & & \\
\hline
\end{tabular}

\section{Multivariate Analysis}

Table 4 showed that there was a direct effects of coping strategy, cancer stage, frequency of chemotherapy, and length of illness from diagnosis on depression in cervical cancer patients. Table 4 showed that depression in cervical cancer patients was directly increased by frequency of chemotherapy $\geq 3$ times $(b=1.80 ; 95 \% \mathrm{CI}=0.11$ to $3.49 ; \mathrm{p}=0.037)$, advance cancer stage $(\mathrm{b}=$ $2.50 ; 95 \% \mathrm{CI}=0.18$ to $4.82 ; \mathrm{p}=0.035$ ), and length of illness from diagnosis $\geq 11$ months $(b=2.27 ; 95 \% \mathrm{CI}=0.57$ to 3.96 ; $\mathrm{p}=0.009$ ).

Table 4 showed that depression in cervical cancer patients was directly decreased by coping strategy $(b=-6.33 ; 95 \%$ $\mathrm{CI}=-8.68$ to $-3.98 ; \mathrm{p}<0.001)$.

Figure 1 showed that depression in cervical cancer patients was indirectly affected by peer support, family support, health personnel support, family income, employment, education, and marital status. 
Shinta et al./ Factors affecting occurrence of depression in cervical cancer patients

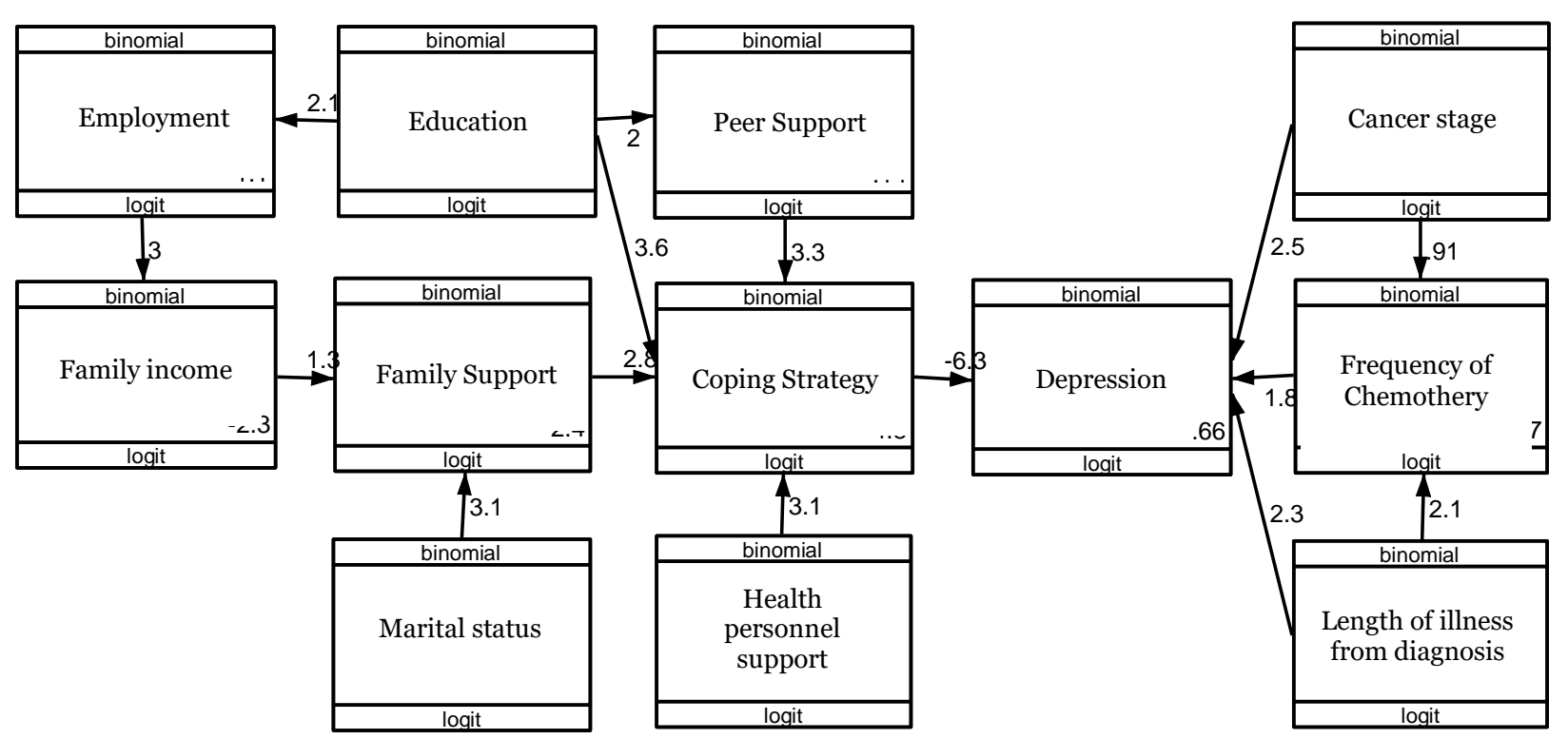

Figure 1. Path Analysis Structural Model

Table 4. Path analysis of factors affecting depression of cervical cancer patients

\begin{tabular}{|c|c|c|c|c|c|}
\hline \multirow{2}{*}{ Dependent Variabl } & \multirow[b]{2}{*}{ Independent Variable } & \multirow[b]{2}{*}{$\mathbf{b}$} & \multicolumn{2}{|c|}{ (95\%) CI } & \multirow[b]{2}{*}{$\mathbf{p}$} \\
\hline & & & $\begin{array}{l}\text { Lower } \\
\text { Limit }\end{array}$ & $\begin{array}{l}\text { Upper } \\
\text { Limit }\end{array}$ & \\
\hline \multicolumn{6}{|l|}{ Direct Effect } \\
\hline \multirow[t]{4}{*}{ Depression } & $\leftarrow$ High Coping Strategy & -6.33 & -8.68 & -3.98 & $<0.001$ \\
\hline & $\leftarrow$ Frequency of chemotherapy $\geq 3$ times & 1.80 & 0.11 & 3.49 & 0.037 \\
\hline & $\leftarrow$ Advanced Stadium & 2.50 & 0.18 & 4.82 & 0.035 \\
\hline & $\begin{array}{l}\leftarrow \text { Length of illness from diagnosis } \geq 11 \\
\text { months }\end{array}$ & 2.27 & 0.57 & 3.96 & 0.009 \\
\hline \multicolumn{6}{|l|}{ Indirect Effects } \\
\hline Frequency of & $\leftarrow$ Advanced Stadium & 0.91 & 0.15 & 1.66 & 0.019 \\
\hline $\begin{array}{l}\text { Chemotherapy } \geq 3 \\
\text { times }\end{array}$ & $\begin{array}{l}\leftarrow \text { Length of illness from diagnosis } \geq 11 \\
\text { months }\end{array}$ & 2.08 & 1.43 & 2.73 & $<0.001$ \\
\hline High Coping & $\leftarrow$ Education $\geq$ SHS & 3.64 & 1.10 & 6.18 & 0.005 \\
\hline \multirow[t]{3}{*}{ Strategy } & $\leftarrow$ Strong peers support & 3.28 & 1.52 & 5.04 & $<0.001$ \\
\hline & $\leftarrow$ Strong family support & 2.76 & 1.05 & 4.48 & 0.002 \\
\hline & $\leftarrow$ Strong support from health personnel & 3.10 & 1.52 & 5.04 & $<0.001$ \\
\hline \multicolumn{6}{|l|}{ Support } \\
\hline Strong Family & $\leftarrow$ Married & 3.12 & 2.07 & 4.16 & $<0.001$ \\
\hline Support & $\leftarrow$ Family Income $\geq \operatorname{Rp} 1,800,000$ & 1.34 & 0.50 & 2.17 & 0.002 \\
\hline $\begin{array}{l}\text { Family Income Rp. } \\
1,800,000\end{array}$ & $\leftarrow$ Occupation(working) & 3.02 & 2.25 & 3.80 & $<0.001$ \\
\hline $\begin{array}{l}\text { Employed } \\
\text { n observation }=200 \\
\text { Log Likelihood }=-572\end{array}$ & $\begin{array}{l}\leftarrow \text { High Education } \geq \text { SHS } \\
25\end{array}$ & 2.08 & 1.41 & 2.74 & $<0.001$ \\
\hline
\end{tabular}

\section{DISCUSSION}

\section{The effect of coping strategy on depression}

The results indicate a high coping strategy to reduce severe depression in accordance with previous studies conducted by Geyciky et al. (2018) in breast cancer patients that there is a negative correlation between depression and active coping strategies. The results of higher BDI scores indicate 
depression occurs in breast cancer patients, but they can cope with active coping strategies (Geyikci et al., 2018).

Murti (2018) states that the biopsychosocial model proposed by George Engel (1977) affects one's health. The state of the soul (psychological factors) underlying a person contributes to the health and manifestation of the person's illness. Psychological problems can affect the health of patients directly or indirectly (Murti, 2018). Breast cancer patients have the skills and strength of coping strategies and recovery from problems and challenges caused by diseases related to many variables, can be evaluated based on characteristics related to the patient, stage of the disease and treatment, and the environment (Tsaras et al., 2018).

\section{The effect of chemotherapy frequ- ency on depression}

The results of this study show the direct influence of the frequency of chemotherapy $\geq 3$ times on severe depression in cervical cancer patients. Chemotherapy is one of the therapies/treatments for cervical cancer (Indonesian Minister of Health, 2018). These results are in accordance with previous studies by $\mathrm{Hu}$ et al. (2018) that depressive symptoms in married cancer patients were influenced by the frequency of chemotherapy $\geq 3$ times (OR $=8,782$, $95 \% \mathrm{CI}=1,894$ to $40,721, \mathrm{p}=0.006$ ) (Hu et al., 2018).

The impact of chemotherapy is biologically affecting mental health. The release of proinflammatory cytokines during cell damage induced by chemotherapy can affect the pathophysiology of mood disorders. Side effects from chemotherapy such as alopecia, nausea and vomiting further increase the risk of depression and anxiety (Shyu et al., 2019).

\section{The effect of the cancer stadium on depression}

The results of this study show the direct effect of advanced stages of increasing severe depression in cervical cancer patients. Advanced stages are associated with the incidence of depression in cancer patients (Wang et al., 2019). Biological factors influence the increased risk of depression at an advanced stage, due to a greater burden of physical symptoms, and advanced age (Fervaha et al., 2018). The stage of breast cancer affects the quality of life of patients, and the length of treatment and inpatient stages, so that it becomes a factor in increasing levels of anxiety and depression (Geyikci et al., 2018).

\section{The effect of how long since it is diagnosed on depression}

The results of this study show the direct influence of the diagnosis duration $\geq 11$ months on severe depression in cervical cancer patients. Psychological stresses including depression and anxiety can occur at any time during the diagnosis of cancer. Depression occurs immediately after diagnosis and continues to increase for up to 5 years (Götze et al., 2019). It is mostly explained that cancer patients experience fatigue for months to years afterwards a diagnosis of breast cancer with these symptoms is associated with greater disability and a worse quality of life (Tsaras et al., 2018).

\section{The effect of the cancer stage on the frequency of chemotherapy}

The results of this study indicate the indirect effect of advanced stages on major depression, through variable frequency chemotherapy. Ramadas (2015) explained that $41.9 \%$ of advanced-stage patients undergoing treatment experienced psychological symptoms (Ramadas et al., 2015). Patients with advanced cancer will influence the developmental disease and cumu- 
lative effects of chemotherapy treatment, resulting in decreased physical and functional capacity (Quist et al., 2015). Cancer patients who have been diagnosed at an advanced stage must undergo treatment, such as chemotherapy or radiation in large quantities will experience emotional distress (Inhestern et al., 2017).

\section{The effect of length of illness from diagnosis on the frequency of chemotherapy}

The results of this study indicate the indirect effect of length of illness from diagnosis $\geq 11$ months on severe depression, through the frequency of chemotherapy. The duration of cervical cancer patients affects the number of frequencies of this type of treatment. One of the therapies in this study is chemotherapy. Long diagnosis increases the risk of depression, anxiety and stress-related disorders, caused by side effects from medical treatment, or medical sequelae of breast cancer (such as lymphedema, numbness in the hands and chest) which can trigger traumatic (Yang et al., 2016). Depressed breast cancer patients are less proactive in seeking care, have more severe symptoms, worse response to systemic therapy, longer recovery times and poor results ( $\mathrm{Ng}$ et al., 2017).

\section{The effect of peers support on the coping strategies}

The results of this study indicate the indirect effect of strong peer support on major depression, through coping strategy. Kroenke et al. (2006) explained that the number of close friends and relatives had an effect on increasing survival following a diagnosis of breast cancer even after being diagnosed with a stage of breast cancer (Salakari et al., 2017). In general, high emotional support from social relationships has been shown to reduce depression (Santini et al., 2015). According to Castro (2013) it can be concluded that all support especially the support of family and friends plays an important role in improving aspects of quality of life in general, satisfaction with health, physical, psychological, social and environmental (Lusiatun et al., 2017).

\section{The effect of family support on the coping strategies}

The results of this study indicate the indirect effect of strong family support on major depression, through coping strategy. According to the research of Wondimagegnehu et al. (2019) that statistically there is a significant difference in the average rank score on social support received from family towards depressed and non-depressed women. Having problems with family is an identified factor in increasing depression (Wondimagegnehu et al., 2019).

The family environment is a source of social support playing a role in patient coping strategies, and in increasing the ability of cancer patients to cope with the disease (Yoo et al., 2014). Van den Brink et al. (2017) concluded that if depressed people experience difficulties in their social relationships, this hinders their recovery (Brink et al., 2017).

\section{The effect of health personnel support on the coping strategy}

The results of this study indicate the indirect effect of strong support of health personnel on major depression, through coping strategies. During the treatment process, cancer patients will experience difficulties. This can be a factor in the level of depression. In this case the need for protective factors to overcome distress includes support from social relations, such as family and professional resources (Salakari et al., 2017). Professional resources working in oncology (eg oncologists, surgeons, radiation oncologists, primary care physicians, nurses, social workers, psychologists) need to receive training in diagnosis and integration of the management of 
Journal of Epidemiology and Public Health (2019), 4(4): 338-350

https://doi.org/10.26911/jepublichealth.2019.04.04.09

various types of disorders in the clinical depression spectrum, so as to manage coping every patient in making decisions (Caruso et al., 2017).

\section{The effect of education on the coping strategies}

The results of this study indicate the indirect effect of $\geq$ Senior highs school education on depression, through coping strategy. Low education is a risk factor for emotional problems in anxiety and depression among cancer patients (Geyikci et al., 2018). Lower education levels were also found as: predictors of psychological comorbidities in patients with breast cancer. It is explained that patients with higher levels of education have a greater chance of being aware of their illness (Srivastava et al., 2016). Other studies suggest that women with high levels of education can influence the information obtained, patients can understand information better, have a good cognitive to be accepted, seek information about their care, thus affecting their coping strategies (Nuryati et al., 2018).

\section{The effect of education on the peers support}

The results of this study indicate the indirect effect of $\geq$ Senior high school education on major depression, through the support of friends. Education is related to one's level of knowledge. According to Cassileth et al. (1987) explain that having knowledge plays a role in decision making. Knowledge in seeking information and actively participating in the environment of friends increases behavior and confidence in recovering from illness. Finding information among patients who have just been diagnosed or and a higher level of education can influence coping strategies (Geyikci et al., 2018). Several studies have shown that receiving education, by increasing social networks such as friendship or friendship work, positively influences social support (Bener et al., 2017).

\section{The effect of marital status on the family support}

The results of this study indicate the indirect effect of marriage on depression, through family support. Partner support is a source of social support for depression (Salakari et al., 2017). Spouse support can eliminate symptoms, and can do better disease management, and improve better psychological well-being and quality of life for cancer patients (Song et al., 2016).

\section{The effect of family income on the family support}

The results of this study indicate that there was an indirect effect of family income $\geq R p$ 1,800,000 against major depression, through family support. Patients suffering from cancer often experience enormous mental stress (depression) from financial burdens (Nipp et al., 2015). Patients who get less family income and do not have a partner will receive less financial support from the family, so they can experience depression (Bener et al., 2017).

Symptoms of anxiety and depression are very common among people with low incomes. Low-income patients with cancer will encounter economic obstacles in the family and other obstacles to cancer care. They need income support because of their cancer, which further increases the economic burden of treating cancer (Hu et al., 2018). Direct expenses for the patient's family are expenditures in health care during the treatment including accommodation costs, without considering health insurance (Delgado-Guay et al., 2015).

\section{The effect of occupation on the family income}

The results of this study indicate the indirect effect of occupation (work) on major depression, through family income. Women who work are less likely to experience 
depression than women who are housewives (Salakari et al., 2017). Most patients not working and having a low monthly income less per month can increase the economic burden and depression.

According to Prastiwi (2012), although treatment costs are covered by BPJS, family health insurance still faces financial difficulties, in which families need a lot of money for operating costs during a gradual and continuous medical examination as well as chemotherapy treatment (Fadhilla et al., 2017). Therefore, it can be concluded that there is financial pressure or financial burden for those who do not work in families to increase depression (Sharp et al., 2015).

\section{The effect of education on occupa- tion}

The results of this study indicate the indirect effect of high school education on major depression, through work. Low education causes people to not have a job. Unemployment status is significantly higher in the likelihood of patients reporting decreased income since diagnosis. This condition develops into a financial burden, such as being young, not eligible for payment for care and too unhealthy to find work while overcoming the demands of cancer treatment (Paul et al., 2016).

Patients with low levels of education and not working have an effect on low knowledge in seeking information. Lack of knowledge about managing the disease and their awareness of controlling risk factors that might cause the disease to get worse and increase depression (Ogoncho et al., 2016).

\section{AUTHOR CONTRIBUTION}

Dewi Shinta is the main researcher who plays a role in research data collection, research article formulation, and data processing. Didik Gunawan Tamtomo played a role in the formulation of the background. RB Soemanto assisted in the formulation of a framework of thought and research discussion.

\section{FUNDING AND SPONSORSHIP}

This study is self-funded.

CONFLICT OF INTEREST

There is no conflict of interest in this study.

\section{ACKNOWLEDGEMENT}

Acknowledgments were conveyed by author to the Director of Dr. Moewardi Hospital, Surakarta for allowing this research to be carried out. Thank you to all the patients who have been willing and cooperative to become research respondents.

\section{REFERENCE}

Adriani RB, Martono, Sulistyowati EC (2017). The effect of depression on the quality of life of patient with cervical cancer at Dr. Moewardi Hospital in Surakarta. Indones J Med, 01(02): 121-128. https://doi.org/10.26911/theijmed.2016.01.02.06.

Bener A, Alsulaiman R, Doodson L, Agathangelou $T$ (2017). Depression, hopelessness and social support among breast cancer patients: in highly endogamous population. Asian Pac $\mathrm{J}$ Cancer Prev, 18: 1889-1896. https://doi.org/10.22034/APJCP.2017.18.7 .1889 .

Brink RHS van den, Schutter N, Hanssen D JC, Elzinga BM, RabelingKeus IM, Stek ML, Comijs HC, et al. (2017). Prognostic significance of social network, social support and loneliness for course of major depressive disorder in adulthood and old age. Epidemiol Psych Sci, 1-12. https://doi.org/10.1017/S2045796017000014. 
Journal of Epidemiology and Public Health (2019), 4(4): 338-350

https://doi.org/10.26911/jepublichealth.2019.04.04.09

Caruso R, Giuliananni M, Riba MB, Sabato

S, Grassi L (2017). Depressive spectrum disorders in cancer: diagnostic issues and intervention. A critical review. Curr Psychiatry Rep, 19(33): 110. https://doi.org/10.1007/s1192001707857.

DelgadoGuay M, Ferrer J, Rieber AG, Rhondali W, Tayjasanant S, Ochoa J, Cantu H, Chisholm G et al. (2015). Financial distress and its associations with physical and emotional symptoms and quality of life among advanced cancer patients. The Oncologist, 1092-1098. https://doi.org/10.1634/theoncologist.2015-0026.

Fadhilla HN, Mudigdo A, Rahardjo SS (2017). Effect of age and socioeconomic status on the quality of life of patients with cervical cancer undertaking chemotherapy at Dr. Moewardi Hospital Surakarta. J Epidemiol Public Healt, 02(01): 11-19. https://doi.org/10.26911/jepublichealth.2017.02. 01.02.

Fervaha G, Izard JP, Tripp DA, Rajan S, Leong DP, Siemens DR (2018). Depression and prostate cancer: A focused review for the clinician. Urol Oncol, ooo: 1-7. https://doi.org/10.1016/j.urolonc.2018.12.020.

Geyikci R, Cakmak S, Demirkol ME, Uguz S (2018). Correlation of anxiety and depression levels with attitudes towards coping with illness and sociodemographic characteristics in patients with a diagnosis of breast cancer. J Neurol Neurosurg Psychiatry, 31(3): 246-257. https://doi.org/10.5350/DAJPN2018310302.

Global Burden Cancer (2019). Indonesia fact sheets. International agency for research on cancer, 256. Retrieved from http://gco.iarc.fr/today/factsheetspopulations.
Götze H, Friedrich M, Taubenheim S, Dietz A, Lordick F, Mehnert A (2019). Depression and anxiety in longterm survivors 5 and 10 years after cancer diagnosis. Supportive Care Cancer, 110. https://doi.org/https://doi.org/10.1007/s00520-019-04805-1.

Hu Y, Ma Z, Zhang H, Gao T, Gao J, Kong Y, Qin Z, Mei S (2018). Prevalence of and factors related to anxiety and depression symptoms among married patients with gynecological malignancies in China. Asian J Psychiatr, 37: 90-95. https://doi.org/10.1016/j.ajp.2018.08.015.

Inhestern L, Beierlein V, Bultmann JC, Möller B, Romer G, Koch U, Bergelt C (2017). Anxiety and depression in working age cancer survivors: A registerbased study. BMC Cancer, 18. https://doi.org/10.1186/s1288501733479 .

Jia Y, Li F, Liu YF, Zhao JP, Leng MM, Chen L (2017). Depression and cancer risk: A systematic review and metaanalysis. Public Health, 149: 138-148. https://doi.org/10.1016/j.puhe.2017.04.026.

Lusiatun, Mudigdo A, Murti B (2017). The effect of selfefficacy, family support, and socioeconomic factors on the quality of life of patients with breast cancer at Dr. Moewardi Hospital, Surakarta. J Epidemiol Public Health, 01 (03): 182-194. https://doi.org/10.26911/jepublichealth.2016.01.03.0 5.

Ministry of Health RI (2018). Decree of the Minister of Health of the Republic of Indonesia number HK.01.07/ MENKES/349/2018 concerning national guidelines for medical services for the treatment of cervical cancer (15). https://doi.org/10.22201/fq.18708404e.2004.3.66178. 
Murti B (2018). Prinsip dan Metode Riset Epidemiologi Edisi ke Empat. Surakarta: Prodi Ilmu Kesehatan Masyarakat, Program Pascasarjana UNS.

Ng GC, Mohamed S, Sulaiman AH, Zainal NZ (2017). Anxiety and depression in cancer patients: the association with religiosity and religious coping. J Religion Health, 56(2): 575-590. https://doi.org/10.1007/s109430160 $267 y$.

Nipp RD, Powell E, Chabner B, Moy B (2015). Recognizing the financial burden of cancer patients in clinical trials. The Oncologist, 572-575. https://doi.org/10.1634/theoncologist.20150068.

Nuryati S, Mudigdo A, Murti B (2018). Path analysis on the influence of educational level, stages of cancer, social support, and coping strategy toward the quality of life of breast cancer patients in Dr. Moewardi Hospital, Surakarta. J Epidemiol Public Health, 02(03): 225-235. https://doi.org/10.26911/jepublichealth.2017.02.03.04.

Ogoncho IM, Omuga BO, Wakasiaka S, Mulva M (2016). Quality of life among gynaecological cancer patients receiving palliative care in Kenya : A crosssectional study. African Journal of Midwifery and Women's Health, 10(1): 2016-2019. https://doi.org/https://doi.org/10.12968/ajmw.2016.10.1.15.

Paul C, Boyes A, Hall A, Bisquera A, Miller A, Brien LO (2016). The impact of cancer diagnosis and treatment on employment, income, treatment decisions and financial assistance and their relationship to socioeconomic and disease factors. Supportive Care Cancer. https://doi.org/10.1007/so0520-016-3323-y.
Quist M, Adamsen L, Rørth M, Laursen JH, Christensen KB, Langer SW (2015). The impact of a multidimensional exercise intervention on physical and functional capacity, anxiety, and depression in patients with advancedstage lung cancer undergoing chemotherapy. SAGE, 1-9. https://doi.org/$10.1177 / 1534735415572887$.

Ramadas A, Qureshi AM, Dominic NA, Botross P, Riad A, Arasoo VJT, Elangovan $S$ (2015). Socio-demography and medical history as predictors of health-related quality of life of breast cancer survivors. Asian Pac J Cancer Prev, 16: 1479-1485. http: //dx.doi.org/10.7314/APJCP.2015.16.4.1479.

Salakari M, Pylkkanen L, Sillanmaki L, Nurminen R, Rautava P, Koskenvuo $M$, Suominen S (2017). Social support and breast cancer: A comparatory study of breast cancer survivors, women with mental depression, women with hypertension and healthy female controls. The Breast, 35 . https://doi.org/10.1016/j.breast.2017.06.017.

Santini ZI, Koyanagi A, Tyrovolas S, Mason $C$ (2015). The association between social relationships and depression: A systerovolas, stefanos mason, catherine maria, josepmatic review. J Affect Disord, 175: 53-65. https://doi.org/10.1016/j.jad.2014.12.049.

Sharp L, Timmons A (2015). Prediagnosis employment status and financial circumstances predict cancer-related financial stress and strain among breast and prostate cancer survivors. Support Care Cancer. https://doi.org/10.1007/soo520-015-2832-4.

Shyu IL, Hu LY, Chen YJ, Wang PH, Huang BS (2019). Risk factors for developing depression in women with cervical cancer: A nationwide population ba- 
Journal of Epidemiology and Public Health (2019), 4(4): 338-350

https://doi.org/10.26911/jepublichealth.2019.04.04.09

sed study in Taiwan. Int $\mathrm{J}$ Womens Health, 11: 135-141. https://doi.org/10.2147/ijwh.s193003.

Song L, Rini C, Ellis KR, Northouse LL (2016). Appraisals, perceived dyadic communication, and quality of life over time among couples coping with prostate cancer. Supportive Care Cancer. https://doi.org/10.1007/s00520016-3188-0.

Srivastava V, Ansari MA, Kumar A, Shah AG, Meena K, Sevach P, Singh OP (2016). Study of anxiety and depression among breast cancer patients from north India. iMedPub $\mathrm{J}, 1-7$. https://doi.org/10.21767/24719854.1 ooo17.

Tsaras K, Papathanasiou IV, Mitsi D, Kelesi M, Zyga S, Fradelos EC (2018). Assessment of depression and anxiety in breast cancer patients : prevalence and associated factors. Psychological Distress in Breast Cancer, 19: 16611669. https://doi.org/10.22034/APJCP.2018.19.6.1661.

Wang B, Li B, Tan S, Zhai J, Chen M (2019). Risk factors for anxiety and depression in Chinese patients undergoing surgery for endometrial cancer 1 Psychiatry Department, Jining Psychiatric Hospital 2 Medical Department, Jining No. 1 People's Hospital 3 School of Mental Health, Jining
Medical. Can J Physiol Pharmacol, (1): 1-17.https://doi.org/10.1139/cjpp-2019-0302.

Wen S, Xiao H, Yang Y (2018). The risk factors for depression in cancer patients undergoing chemotherapy: A systematic review. Supportive Care Cancer, 57-67. https://doi.org/10.1007/soo520-018-4466-9.

WHO. (2019). Cervical cancer. Retrieved from https://www.who.int/cancer/cervicalcancer.

Wondimagegnehu A, Abebe W, Abraha A, Teferra S (2019). Depression and social support among breast cancer patients in Addis Ababa, Ethiopia. BMC Cancer, 1-8. https://doi.org/https://doi.org/10.1186/s12885-019-6007-4.

Yang H, Brand JS, Fang F, Chiesa F, Johansson ALV, Hall P, Czene K. (2016). Disorders in patients with invasive and in situ breast cancer. Int J Cancer, oo. https://doi.org/10.1002/ijc.30514.

Yoo W, Shah DV, Shaw BR, Kim E, Smaglik P, Roberts LJ, Hawkins RP, Pingree S et al. (2014). The role of the family environment and computer-mediated social support on breast cancer patients coping strategies. $\mathrm{J}$ Health Commun, 37-41. https://doi.org/10$.1080 / 10810730.2013 .864723$. 